\title{
ENERGY UTILIZATION AND RENEWABLE SOURCES IN INDIA: FUTURE PROSPECTS
}

\author{
JAYA SINGH
}

ABES Engineering College, Ghaziabad, Uttar Pradesh, India

\begin{abstract}
The increasing demand in power arising out of economic activities and an ever escalating population has not been covered due to lack of investment in the infrastructure needed to meet the power requirements. Energy projection keeping in mind the projected economic growth rate indicates a geometric rise in total energy demand by the year 2030. Sustainable energy resources will have the fastest growing rate in the electricity sector, given that almost $30 \%$ of power demands in 2023, up from $24 \%$ in 2017. In such manner full exploitation and advancement of sustainable power source assets will give a generally productive and successful method for accomplishing clean energy makeshift in India. India's capacity bushel has a blend of the total assets required for shifting towards sustainability. Merger of technology with social and political flexibility can help in expansion of methods to create a reasonable framework along with a growing focus on advancing and building the inexhaustible resources of sustainable energy sources present in the nation, as well as for improvement of the security of the grid. In this paper, current and future viewpoint of energy usage and sustainable power source choices in India are analyzed and examined from the stance of the reasonable form of developments.

KEYWORDS: Biomass, Hydro, Renewable Energy, Solar, Wind
\end{abstract}

Received: Jun 08, 2020; Accepted: Jun 28, 2020; Published: Sep 16, 2020; Paper Id.: IJMPERDJUN20201291

\section{INTRODUCTION}

India has a high populace development rate in the world. Power sector has been seen as the most significant structural block in the human growth. One of the vital factors which influences the dependency upon the renewable energy in any country, is the exploitation of conventional energy sources.. The reality of the substantial dependency on thermal, oil, and gas as the fundamental source of power as well as revenue generation has now led to the depletion of these resources at an extremely fast rate. The byproduct linked with the conventional strategies of power generation has also led the world to a stage where it has become unavoidable to make a paradigm shift to the clean and sustainable sources of energy. Renewable energy resources are unpolluted source of energy with less carbon emissions or pollution [1-2].

As per MNRE the new and renewable energy sources are required which can lead to the building of basic structure to improve the power security of nation. Advancement of financial acquisition of utility design along with innovation and administrative determination can help in obtaining the required goals of energy [3]. By reducing dependency on fossils fuels and thermal products which records for $90 \%$ of the $\mathrm{CO} 2$ outflow and which prompts a global temperature boost the world can be made livable for longer duration [4]. The world is now moving towards sustainable power hotspots for energy usage. With the ongoing quick improvement in innovation and increased interests of all nations for low emissions of $\mathrm{CO} 2$, the usage of sustainable power sources shows promising possibilities for power networks. From the specialized and non-conservative point of view, it is believed that fossils 
based energy will be substituted with sustainable power source in the very near future [5].

India is blessed with more than one sustainable energy resource, e.g. wind, sun, hydropower and biomass are abundant to investigate and to open the doors for energy conservation [6-7]. Additionally, 100\% of power utilization from sustainable power sources has even been accomplished in some areas. At the same time, micro grid innovations give an adaptable and coordinated stage for the improvement of sustainable power source. In view of the power requirements, it is reasonable for India to adapt the concept of micro grid in the remote areas [8]. This paper gives a brief outline of different sustainable power source assets, their status in India, the financial effect of sustainable power source assets, challenges related to it, and the eventual fate of sustainable energy resources in India [9].

\section{PRESENT POSITION OF RENEWABLE ENERGY IN INDIA}

Throughout the existence, sustainable power source segment has developed as a huge player in India particularly emerging as the prime force behind the economic growth. This requires rigorous initiation from administration and motivation supported by turn of events while emerging as the fundamental source of the country's power needs [10]. The Indian Government has extended the objective of setting of sustainable power source ability to $175 \mathrm{GW}$ continuously before 2022 which incorporates 100 Gigawatts from sun based, 60 Gigawatt from wind, 10 Gigawatt from bio-force, in addition to 5 GW from little hydro-power. By accomplishing $36 \mathrm{GW}$ power creation associated with renewable sources India stands at a high position in the world [11]. The policies as well as regulations had been a tool for support to the success and expansion of solar power across the country. This paper presents current scene of technology, achievements, policy framework, various encouraging schemes and regulation quality control structure prevalent in India [12]. Here in this paper has been presented current position availability; major accomplishments and forthcoming scope of sustainable resources opportunity in India [13].

\section{Solar Power}

Solar energy has now become one of the fast emergent industries in a developing nation like India. The installed capacity of solar energy now reached $32.52 \mathrm{GW}$ as of 31 March 2020. The sunlight-based energy target was expanded to $100 \mathrm{GW}$ of solar capacity (with 40 Gigawatts from the roof tops) by 2022, targeting a \$ 100 billion investment. India has immense potential for sun-based energy. Around 5000 trillion electricity units every year are radiated in to the area of the Indian Territory and most of the parts obtain from 4 to 7 units of electricity per square meter per day [14]. Therefore, both innovation and demand can course the transformation of solar irradiation into energy. To be specific, thermal radiation obtained by sunlight and the solar photovoltaic can be adequately bridged giving immense versatility to orient solar power in India. It also provides the capacity to produce energy and transmit it to premises and allows the option for fast expansion of transmission lines to remote areas with short delivery times [15-16].

Off-grid decentralization and applications for low power demands will be valuable from the point of view of the provincial diversity and will meet other vital requirements for resistive, heating and cooling purposes both in rural and in urban territories. From the point of view of the security of smart grid, solar energy is the safest [17]. Hypothetically, a small part of the territory which is fully sun-oriented (each time it is successfully captured) can meet the capacity requirements of the entire nation. It is also true that, given the enormous size of the nation's poor and unattended population, every effort should be made for the easy reach and cost effective energy to the society at the last stair [18]. Solar energy can be created through a photovoltaic cell made from semiconductors and through solar collectors arranged in 
a system. The power incident due to sunlight outside the earth's atmosphere is $1016 \mathrm{~W} / \mathrm{m} 2$, although the requirement as per current demand for progressive world is around $1013 \mathrm{~W} / \mathrm{m} 2$ [19]. However, the government's goal of having 20 GigaWatts of sunlight-based solar energy up to 2022 was pursued four years before the plan for Jan, 2018, by means of solar parks and solar panels on the roof. India set another target to achieve $100 \mathrm{GW}$ of solar energy, wind energy of 60 GW, biomass of $10 \mathrm{GW}$ and $5 \mathrm{GW}$ by low hydropower by 2022 [20]. India is the first nation around the globe to establish a MNRE department in government ministry in the mid of 1980, and its open areas means that this department in the country is heading for improving the sun-based energy industry in its territory. The International Solar Alliance was established on Nov 30, 2015 by PM Narendra Modi together with French Prime Minister François Hollande [21]. ISA is a collusion of 121 rich sun-based nations that lie mainly or completely in middle of Tropic of the Cancer and Tropic of the Capricorn. Several nations outside of this territory have also joined this international alliance. The ISA plans to advance and create sun oriented force among its individuals and has the target of assembling $\$ 1$ trillion of venture by 2030[22]. National Institute of Solar Energy is an exploration organization specific for sunlight based projects. It goes under authoritative control of MNRE. It is a self-ruling foundation. This establishment bolsters the national sun powered strategic giving satisfactory examines and advances.

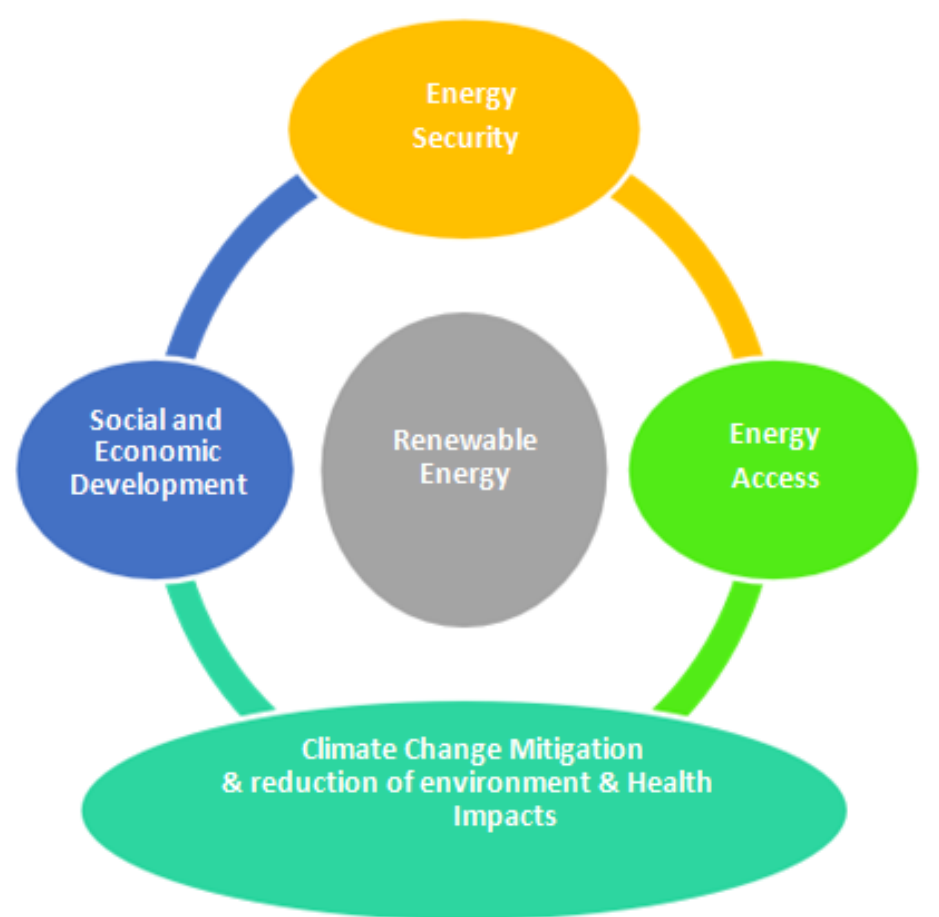

Figure 1: Renewable Energy Benefits. 


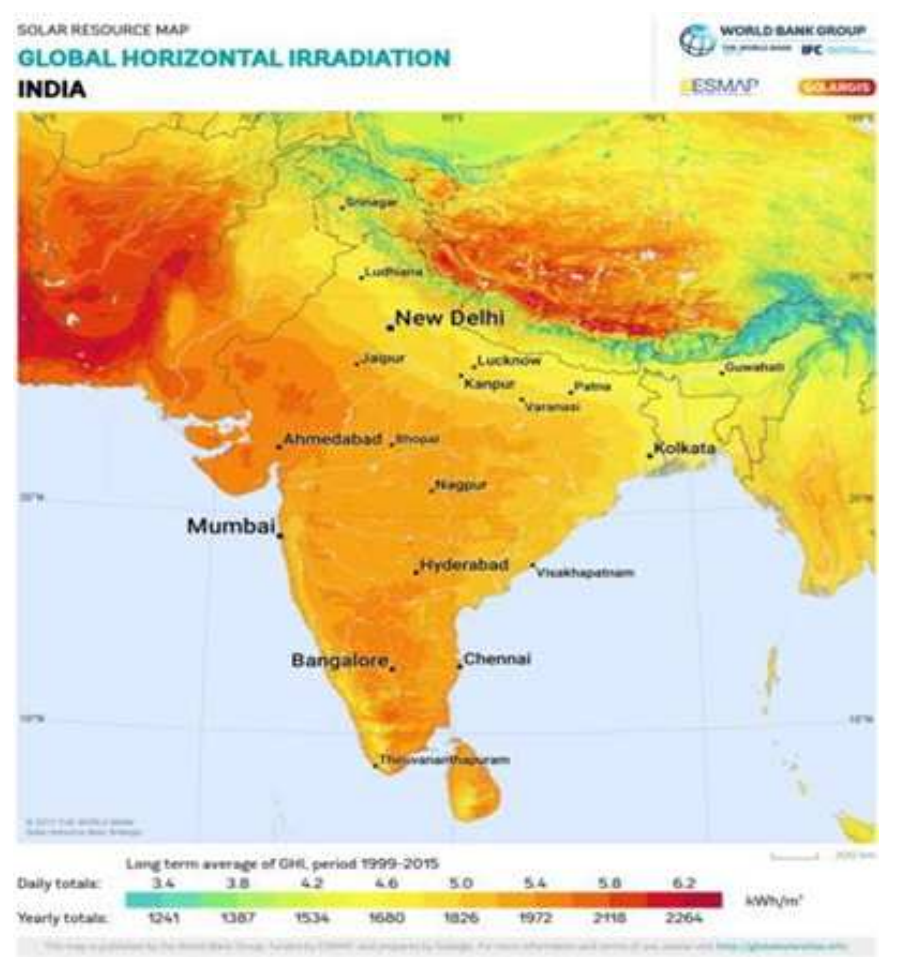

Figure 2: Solar Irradiance Map for India (Source ESMAPS).

\section{Wind Energy}

Winds are perplexing component which includes the process of earth's rotation, heat received from the sun, cooling impact of oceanic areas, polar ice structure, temperature slopes among earth and seas and physical impacts of huge mountains and their snags. The Potential associated with wind power has been evaluated at $103 \mathrm{GW}$ taking locales having power of wind thickness more prominent than $200 \mathrm{Watt} / \mathrm{m}^{2}$ at around $80 \mathrm{~m}$ center tallness with at least $2 \%$ land accessibility in potential zones for building wind ranches @ $9 \mathrm{MW} / \mathrm{Km}^{2}$ [23]. Wind source is turning into a promising elective energy source as innovation leads the area of research. Throughout the years, there has been an impressive increment in wind-driven turbines because of fast progression in the turbine technologies [24].

Although India is much interested and convinced from the methodically designed breeze farms for Denmark or the United States, the continued national strategy for wind has led India to stand as a nation having largest wind energy potential worldwide [25]. As of June 30, 2018, the wind energy capacity introduced in our country was 34,293 MW. Wind has the share of $10 \%$ of the entire electric utilities in India. India has developed an inspirational goal to create $60 \mathrm{GW}$ of intensity from wind farms by 2022.

As part of the national program for assessing wind resource, the Ministry through the National Wind Energy Institute, Chennai (Ongoing Wind Technology Center) and the state nodal agency had submitted and verified 794 monitoring stations for Wind (WMS) at a height varying from $20 \mathrm{~m}$ up to $120 \mathrm{~m}$ across the country as of December 31 , 2014. India is ranked as fifth largest creator of wind energy in the entire globe after Denmark, Spain, Germany and United States [26]. The average annual thickness of the most obvious breeze power of $200 \mathrm{~W} / \mathrm{m}^{2}$ at $50 \mathrm{~m}$ sculpture was recorded at around 211 breeze observation stations ranging in 13 states and districts affiliated to be explicit Andaman Nicobar, Karnataka, Gujarat, Kerala, Andhra Pradesh, Lakshadweep, Madhya Pradesh, Orissa, Rajasthan, Tamil Nadu, Uttarakhand and West Bengal. The energy potential of the Indian breeze is estimated at 37,505 GW until 2019 [27]. 
The government of India is now trying to focus on policy framing to attract investors in field of wind energy to promote wind power. Now NIWE along with government of India prepared a policy framework for regulation and policy framework for wind energy power production and connect to the grid [28-29].

\section{Bioenergy}

Biomass is a resource of a sustainable energy source obtained from carbonaceous wastes from various human and earthly creatures. Bioenergy incorporates biomass energy, biogas cogeneration, biomass gasifier, bioethanol and biodiesel [30]. Biomass removes carbon from the earth as it develops, at which point it returns it when burned. Given its tropical area, inexhaustible daylight, and downpours, India has an ideal area for biomass use [31].

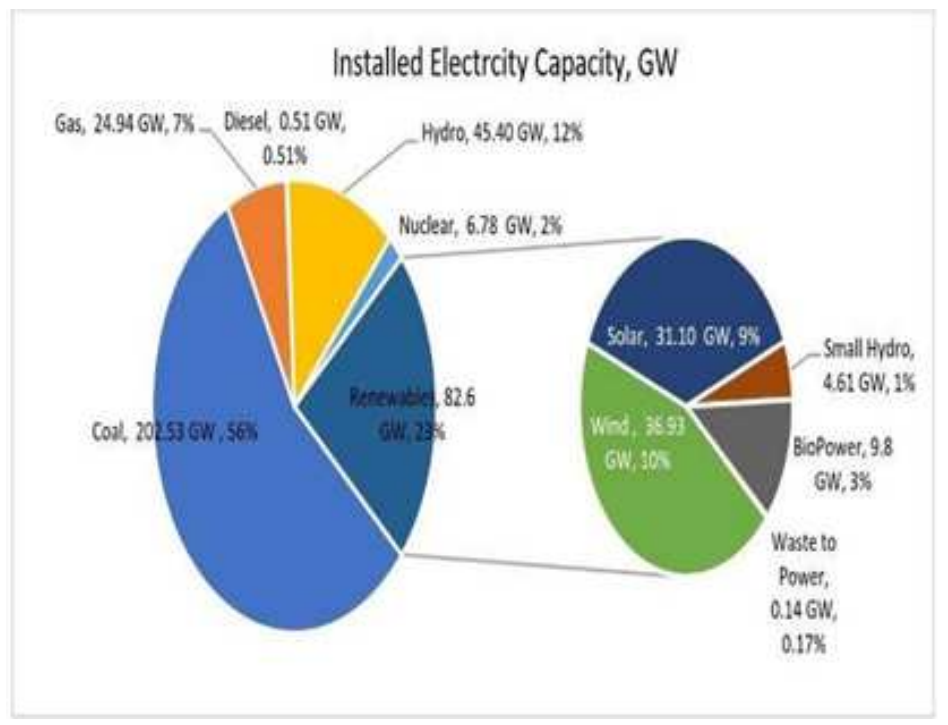

Figure 3: Installed Electricity Capacity in India. (Source MNRE, GOI).

Table 1: Introduced Grid Intuitive Sustainable Force Limit (Barring Enormous Hydropower) Starting at 31 March 2020 (Source MNRE)

\begin{tabular}{|l|c|c|}
\hline \multicolumn{1}{|c|}{ Resource } & $\begin{array}{c}\text { Installed Power } \\
\text { (Gigawatt) }\end{array}$ & $\begin{array}{c}\text { 2022 GOAL } \\
\text { (Gigawatt) }\end{array}$ \\
\hline Wind energy & $37.28 \mathrm{GW}$ & 60 \\
\hline Solar based energy & $32.52 \mathrm{GW}$ & 100 \\
\hline Biomass energy & $9.94 \mathrm{GW}$ & 10 \\
\hline Power from Waste & $18.68 \mathrm{GW}$ & \\
\hline Hydro Power & 4.686 & 5 \\
\hline TOTAL & 89,3915 & 175 \\
\hline
\end{tabular}

\section{Small Hydro Power Plants}

India is the seventh leading producers of hydroelectric power on the planet. Hydro plants in India under $25 \mathrm{MW}$ limit are named 'Little Hydro Power' and is considered as a 'sustainable power source' [32]. Small hydro power with a overall capacity of approx 4,380 MW have been installed up till now. Hydropower is an elective wellspring of sustainable power source which changes over potential due to active rate of conversion of running water into electricity. Approximately 17 percent of hydro energy with a potential around $150 \mathrm{GW}$ has been tapped up till now. In India installed capacity of about $25 \mathrm{MW}$ comes under the small hydro power energy [33]. MNRE encourages the main power project developments throughout the India [34]. 


\section{INDIAN RENEWABLE ENERGY POLICIES AND ACHIEVEMENTS}

The government of India has to play a vital role for developing and the advancing sun oriented energy technology. The government has been the specialized point of convergence for the National Solar Energy Program [35]. The offices made at the Center to empower it to play out its job are the most progressive and one of a kind in India and South Asian countries. Specialized help to industry for advancement for sunlight based vital items, development of national standards for sun oriented gadgets has become necessary for regulating the industrial production. Establishments of testing convention for sun oriented farms and sun oriented PV gadgets for achieving consistency in the testing done by different approved offices inside the country is also one of the requirements [36]. Planning of various specialized reports and papers on significant sun based farms for example sun-powered thermal power generation, sun oriented refrigeration, and sunlight based desalination, bio fuel and also required. Resuscitating $50 \mathrm{KWh}$ Solar Thermal Power Plant by indigenizing some basic segments like Heat Collection Elements Plant is being used as R\&D, Demonstration and Educational facility [37-38]. Following are the areas of scope in India.

- Robust demand: With the development of the Indian economy, energy use is expected to reach $15,280 \mathrm{TWh}$ next to 2040 .

- Escalating Investments: With the focus on the Indian government's goals, the area has become very attractive to Indian financial specialists. It is required to attract businesses of up to $\$ 80$ billion ( $€ 70$ billion) in the upcoming four years.

- Economic Benefits: India has consistent daylight accessibility and has a huge hydropower potential.

In the previous five years the cost of sustainable power source has diminished radically, from Rs. $5.05 / \mathrm{kWh}$ in 2014 to Rs. 2.44/kWh in 2017 for solar utilization.

\section{CHALLENGES AND GOALS FOR RENEWABLE ENERGY}

The Indian government expanded the sustainable energy source capacity target to $175 \mathrm{GW}$ continuously in 2022 , which includes 100 Gigawatt by solar itself, 60 Gigawatt in wind energy, 10 Gigawatt in bioenergy and 5 Gigawatt in low hydro power [39].

There are several challenges in executing renewable energy expansion targets that include:

- Almost all renewable energy sources suffer high installation costs. Wind power, small hydropower and biomass have been substantially verified to be considered comparable or nearly analogous to traditional energy technologies in a limited financial sense and possibly also cheaper in light of full life cycles. However, solar energy is not expensive comparable to limited economic importance. However, this is expected to be comparable in cost terms in a few years with new technological developments [40].

- They depend on certain conditions. The wind energy scheme cannot be implemented in a region with insufficient wind. Small hydro power cannot be used in an area without small rivers.

- Development and updating of existing structures based on new innovations.

- Coordinate the main stakeholders (state and national regulating authorities as well as ministries, producers) to allow satisfactory liberty and the flexibility of process in the implementation of smart grids. 
With the right interests in green innovations, it can be said that India is in a very favorable position to achieve the ambitious goals of a sustainable energy source. Interest in cleaner form of energy will play a key role in supporting the nation's change in a fully practical framework of policies. It is far from a hidden reality that India is actually the fourth major carbon producer in the globe with an absolute population of 1.3 billion. In the years to come, India has gained critical grounds in the field of sustainable energy source. Global concerns about environmental change have prompted the legislator to develop a point-by-point plan for a perfect and workable force for all [41].

According to the examination by the College of Innovation in Finland, because of a bounty of supportable sustainable assets, there is a huge potential for India to move into a plenteous inexhaustible force creation by 2050 . This is conceivable in the event that India can utilize refined advances. Sustainable power source's improvement in India looks brilliant as around 293 organizations worldwide and domestic organizations had a resolution to create $266 \mathrm{GW}$ of solar based, wind based, small hydro and biomass waste based plants in India in the coming decade.

The Universal Account Partnership, the risk arm of World Bank Gathering, intends to contribute approximately \$ 6 billion ( $€ 5$ billion) by 2022 in some sustainable and sustainable programs in India. With a speculative capacity of INR 15 trillion ( $€ 187$ billion) for the subsequent 4-5 years in the Indian force area, it shows huge opportunity for opening doors in the era of energy, transport, transmission and equipment [42]. In addition, strong growth is expected over the next decade as capacity spending increases, likely due to the development of pure volume along the way of electric vehicles [43].

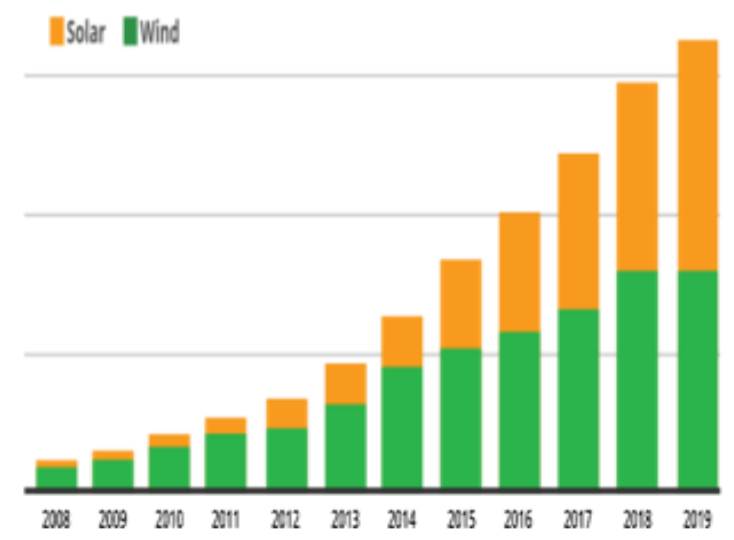

Figure 4: Escalating Renewable Energy Capacity of India.

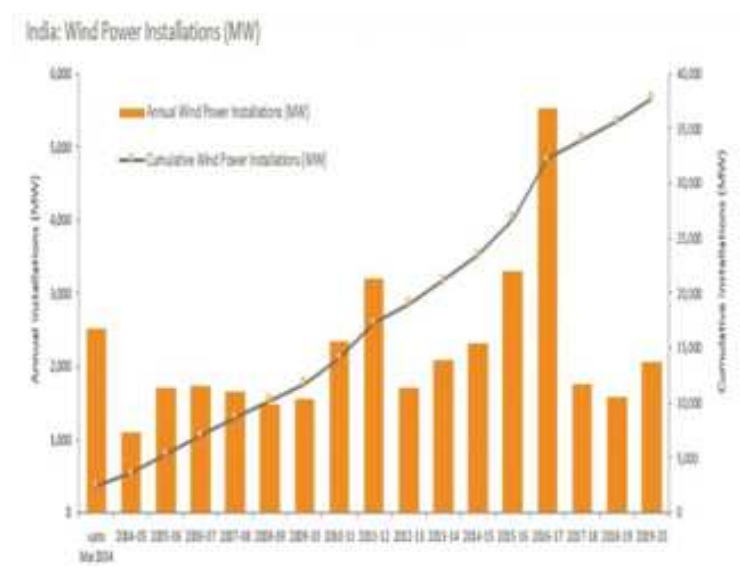

Figure 5: Growth of the Wind Power Generation in India from 2004-2020. 


\section{CONCLUSIONS}

It can be said that there are many sustainable sources of energy in India to overcome the barriers between energy supply and demand. So a country like India should constantly and judiciously invest in renewable energy sources to make available different types of sustainable energy sources with the aim to utilize more. Updated innovations must be framed into a perfect and secure place for our future scenarios. With the extension of the sustainable power sources through renewable sources, air quality can be improved, reduced average temperature worldwide or global warming, make new enterprises and occupations, and help to move the earth towards a cleaner, more secure along with reasonable power. Private participation in the preliminary stages creates a healthy environment which has added to the accomplishment of sustainable power in the nation.

\section{REFERENCES}

1. ZM. Hasanuzzaman, N. A. Rahim, M. Hosenuzzaman, R. Saidur, I. M. Mahbubul, and M. M. Rashid, "Energy savings in the combustion based process heating in industrial sector," Renewable \& Sustainable Energy Reviews, vol. 16, no. 7, pp. 45274536 ,

2. M. A. Khan, M. Z. Khan, K. Zaman, and L. Naz, "Global estimates of energy consumption and greenhouse gas emissions," Renewable and Sustainable Energy Reviews, vol. 29, pp. 336-344, 2014.

3. IEA, Renewable energy outlook/Global Energy Trends, 2016.

4. Choi, Seungho, et al. "Success Factors for Luxury e-commerce: Burberry's Digital Innovation Process." International Journal of Information Systems Management Research and Development (2014): 1-10.

5. L. B. Becker, Renewable Energy Policies and Barriers, vol. 5 of Encyclopedia of Energy, Academic/Elsevier, New York, NY, USA, 2014.

6. Sanjay Kumar, Atul Sharma wind power developments in India renewable sustainable energy 48(2015)pp 264-275

7. Kumar A, Kumar K, Kaushik N, Sharma S, Mishra S. Renewable energy in India: current status and future potentials. Renewable and Sustainable Energy Reviews 2010;14:2434e42.

8. Agrawal, Kalpana, and HuzefaJaliwala. "Effect of social media on e-purchase amongst youth." International Journal of Business Management \& Research 3.2 (2013): 131-136.

9. Renewable Energy Physical Progress as on 31-03-2016". Ministry of New \& Renewable Energy, GoI. Retrieved 14 June 2017.

10. R. Saidur, M. Rezaei, W. K. Muzammil, M. H. Hassan, S. Paria, and M. Hasanuzzaman, "Technologies to recover exhaust heat from internal combustion engines," Renewable and Sustainable Energy Reviews, vol. 16, no. 8, pp. 5649-5659, 2019.

11. Deshmukh, S., and G. T. Thampi. "Transformative effect of e-commerce and m-commerce on national productivity in India'." International Journal of Applied Engineering Research and Development (IJAERD) 4.2 (2014): 65-80.

12. Kaygusuz K. Energy services and energy poverty for sustainable rural development. Renewable and Sustainable Energy Reviews 2011;15:936e47.

13. REO, "Renewable energy outlook," World Energy Outlook 2012, 2012,

14. M. C. Chuang and H. W. Ma, "An assessment of Taiwan's energy policy using multi-dimensional energy security indicators," Renewable and Sustainable Energy Reviews, vol. 17, pp. 301-311, 2013. 
15. Chhanga, Devji, and Xitij Shukla. "Fossick: An implementation of federated search engine." International Journal Of Computer Science Engineering And Information Technology Research (IJCSEITR) 6 (2016): 69-78.

16. IEA, Energy Security and Climate Change Policy Interactions, An Assessment Framework, 2004.

17. N. C. Batista, R. Melício, J. C. O. Matias, and J. P. S. Catalão, "Photovoltaic and wind energy systems monitoring and building/home energy management using ZigBee devices within a smart grid, ” Energy, vol. 49, no. 1, pp. 306-315, 2013.

18. IEA, “Renewable energy outlook," Global Energy Trends, 2013

19. Ministry of New and Renewable Energy, Government of India, “Annual Reports 2016-2017”, 2016, [Online], Available: http://mnre.gov.in/filemanager/annual-report/2016017/EN/pdf/1.pdf [Accessed: July 6, 2017]

20. Ministry of New and Renewable Energy, Government of India,

21. Ayoub, M., \& Abdullah, A. Z. (2012). Critical review on the current scenario and significance of crude glycerol resulting from biodiesel industry towards more sustainable renewable energy industry. Renewable and Sustainable Energy Reviews,16, 2671-2686.10.1016/j.rser. 2012.01.054

22. gov.in/file-manager/UserFiles/mission_document_JNNSM.pdf, [Accessed : July 14, 2017]

23. GeoffereyHeal, The Economic of Renewable Energy. Working paper Series no, 15081 National bureau of economic research Cambridge, $M A(2017)$

24. Asumadu Sarkodie, S., \&Owusu, P. A. (2016d). The potential and economic viability of solar photovoltaic in Ghana. Energy Sources, Part A: Recovery, Utilization, and Environmental Effects. doi:10.1080/15567036.2015.1122682

25. Leung Y.C Dennis, Yuan Yang “Wind Energy development and its environment impact a review” renew sustainable energy rev, 16(12) pp 1031-1039

26. National Institute of Solar Energy, Government of India, [Online],

27. Available: https://nise.res.in/// [Accessed: July 10, 2018]

28. "Small Hydro". Government of India Ministry of New and Renewable Energy. Retrieved 6 April 2019.

29. Sanjay Kumar, Atul Sharma, Anil Sharma, "Wind energy status in India a short review “, renewable sustainable energy rev.,16(2015)pp,1157- 1164

30. National offshore wind energy policy, ministry of new and renewable energy government of India (wind energy division) no 51/58(cab,)/2015-WE accessed on 2018

31. National Institute of Wind Energy, Government of India, [Online], Available: http://niwe.res.in/ [Accessed: July 10, 2019]

32. Ministry of New and Renewable Energy "Vision and Mission", [Online],

33. Available:http://mnre.gov.in/mission-and-vision-2/contact-us/state-nodal agencies// [Accessed: July 10, 2017]

34. Ministry of New and Renewable Energy, Government of India,

35. http://mnre.gov.in/file-manager/UserFiles/draft-rea-2015.pdf,

36. National Institute of Bio-Energy Government of India, Available: http://nibe.res.in/ [Accessed: July 10, 2018]

37. Ali RejaOsmani, “ Conventional Energy to Renewable Energy

38. Perspectives for India “, 2014, The NEHU Journal, Vol XII, No. 2, July-December 2014, pp. 41-60, ISSN. 0972 - 8406

39. International Renewable Energy Agency, "30 Years of Policies for Wind.Energy”,2013 
40. Balat H. A renewable perspective for sustainable energy development in Turkey: the case of small hydropower plants. Renewable and Sustainable Energy Reviews 2007;11:2152e65.

41. Planning Commission, Government of India, "Draft report of the exp pp 245-564

42. .Ministry of New and Renewable Energy Government of India, "Vision and Mission", [Online], Available: http://mnre.gov.in/mission and vision-2/mission-and-vision 2018.

43. Verbruggen, A., Fischedick, M., Moomaw, W., Weir, T., Nadaï, A., Nilsson, L. J., Sathaye, J. (2010). Renewable energy costs, potentials, barriers: Conceptual issues. Energy Policy, 38, 850-861.10.1016/j.enpol.2009.10.036

44. Verbruggen, A., Fischedick, M., Moomaw, W., Weir, T., Nadaï, A., Nilsson, L. J., Sathaye, J. (2010). Renewable energy costs,

45. Li CB, Rimali V, Tang M, Nayer C Design and implementation of standalone smart grid employing renewable energy resources on island of Singapore "Proceeding of IEEE Asia symposium on electromagnetic compatibility. 2016 p.442-42

46. Woodruff A the potential for renewable energy to promote sustainable development in pacific island countries in proceeding of the 30th conference of the international association for energy economics 2016

47. G.Tina, S.Gagliano "hybrid solar and wind power system probablistic modeling for long term performance assessement " Solar energy, vol.80,pp.578-588,2016 